\title{
Immunolocalization of $\mathrm{MHC}-\mathrm{II}^{+}$cells in the ovary of immature, young laying and old laying hens Gallus domesticus
}

\author{
A. Barua and Y. Yoshimura* \\ Graduate School for International Development and Cooperation, Hiroshima University, Higashi-Hiroshima 739-8528, Japan
}

\begin{abstract}
The aim of this study was to localize major histocompatibility complex class II positive (MHC-II') cells in the hen ovary, and to determine the effects of ageing and sex steroids on their frequency. Cryostat sections of ovarian tissues of immature, young laying and old laying hens and those of immature hens treated with or without diethylstilboestrol or progesterone were prepared. Sections were immunostained for MHC class II antigens using mouse anti-chicken MHC class II monoclonal antibody and observed under a light microscope. Positive cells were counted using a computer-assisted image analyser. MHC-II ${ }^{+}$cells were localized in the ovarian stroma and theca layer of primary follicles in all birds examined. The frequency of $\mathrm{MHC}-\mathrm{II}^{+}$cells in the stroma and theca of primary follicles (approximately $400-600 \mu \mathrm{m}$ in diameter) was significantly greater in young laying hens than it was in immature and old laying hens $(P<0.01)$. In the stroma and the theca of primary follicles of diethylstilboestrol-treated birds, the frequency of $\mathrm{MHC}-\mathrm{II}^{+}$cells was significantly greater than it was in the stroma and theca of control and progesterone-treated birds $(P<0.01)$. Progesterone had no significant effect when compared with controls. These results indicate that both the ovarian stroma and theca of follicles in the hen ovary contain $\mathrm{MHC}^{-\mathrm{II}^{+}}$cells, the frequency of $\mathrm{MHC}-\mathrm{II}^{+}$cells increases in association with sexual maturation and decreases thereafter during ageing, and oestrogen may be one of the factors enhancing the induction of $\mathrm{MHC}-\mathrm{II}^{+}$cells in the ovary.
\end{abstract}

\section{Introduction}

Major histocompatibility complex class II (MHC class II) molecules are the cell surface glycoproteins expressed by antigen-presenting cells, such as macrophages, B cells and activated $\mathrm{T}$ cells, that play a central role in immunoregulation (Vainio et al., 1987; Bourlet $e t$ al., 1988). In addition to the classical antigen-presenting cells, some non-immune cells, such as gut epithelium (Bland, 1988) and luteal cells (Benyo et al., 1991) in mammals, are also reported to express MHC class II antigens. MHC class II molecules are essential for the stimulation of $\mathrm{CD} 4 \mathrm{~T}$ cells to elicit immune responses against pathogens (Benacerraf, 1981; MacCubbin and Schierman, 1986; Vainio et al., 1987). In chickens, many pathogenic agents can infect ovarian tissues (Blaxland et al., 1982; Keller et al., 1995) and, if there are antigen-presenting cells bearing MHC class II molecules in the ovary, they may play significant roles in defending ovarian tissues from infection. In addition to disease resistance, cells containing MHC class II antigens are involved in the modulation of ovarian functions, such as regression of corpus luteum (Pate, 1995; Petrovska et al., 1996), degradation of atretic follicular tissues (Fujiwara et al., 1993), premature ovarian failure (Hill

*Correspondence.

Received 24 September 1998. and Anderson, 1990) and certain ovarian autoimmune disorders (Bottazzo et al., 1983) in mammals. Chicken MHC class II antigens are similar in structure and function to those

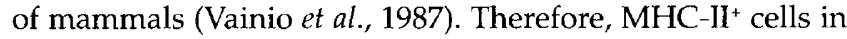
the chicken ovary may play significant roles in disease resistance as well as controlling ovarian remodelling.

In general, immune function decreases with ageing (Hirokawa, 1992). Tada (1992) reported that in aged mice (18 months old), the number of $\mathrm{MHC}^{-\mathrm{II}^{+}}$cells in lymphoid tissues was lower than it was in young mice. In mammals, oestradiol stimulates the expression of MHC class II antigens in the female reproductive tract (Head and Gaede, 1986; Prabhala and Wira, 1995), whereas progesterone suppresses the induction of MHC class II antigens (Pate, 1995). These results indicate that ageing and sex steroids may affect expression of MHC class II antigens. The presence of receptors for oestrogen (Yoshimura et al., 1995), androgen (Yoshimura et al., 1993) and progesterone (Yoshimura and Bahr, 1991) in the chicken ovary indicates that ovarian tissues are target sites for the sex steroids. Immunoglobulincontaining cells and macrophages have been located in the chicken ovary, and their numbers are increased during sexual maturation and by the stimulation of oestrogen (Barua et al., 1998a,b). Therefore, the population of $\mathrm{MHC}-\mathrm{II}^{+}$ cells in the hen ovary may be affected by ageing and sex steroids. However, there has been no report of the 


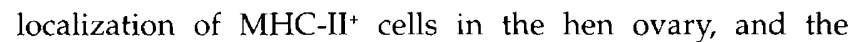
mechanism by which their frequency is regulated remains to be investigated. The aim of the present study was to localize MHC-II+ cells in the ovarian stroma and follicles, and to determine the effects of ageing and sex steroids on their frequency in hens.

\section{Materials and Methods}

\section{Birds}

Immature and mature White Leghorn hens were kept in individual cages under a light regimen of $14 \mathrm{~h}$ light and $10 \mathrm{~h}$ dark and provided with feed and water ad libitum. In the experiment to examine the effects of sexual maturation and ageing on the frequency of $\mathrm{MHC}-\mathrm{II}^{+}$cells in the ovary, the birds were divided into three groups ( $n=5$ birds each): an immature bird group (approximately 50 days old), a young laying hen group (approximately 180 days old and laying five or more eggs in a sequence) and an old laying hen group (approximately 450 days old and laying two or three eggs in a sequence). Five immature birds ( 30 days old) in each group were injected i.m. daily with diethylstilboestrol (DES, an analogue of oestrogen, $1 \mathrm{mg} \mathrm{day}^{-1}$ ), progesterone (1 mg day $^{-1}$ ) or sesame oil (control, $0.1 \mathrm{ml} \mathrm{day}^{-1}$ ) for 7 days to examine the effects of sex steroids on the frequency of MHC-II ${ }^{+}$cells. Diethylstilboestrol (Nacalai Tesque, Kyoto) and progesterone (Sigma, St Louis, MO) were dissolved in sesame oil (Nacalai Tesque) at a concentration of $10 \mathrm{mg}$ $\mathrm{ml}^{-1}$ before injection.

\section{Tissue preparation}

Immature, young laying and old laying hens were killed by decapitation, and ovarian stroma that contained primary follicles (approximately $400-600 \mu \mathrm{m}$ in diameter) were collected. Young and old laying hens were killed just after oviposition, that is, approximately $30 \mathrm{~min}$ before the expected time of ovulation (Warren and Scott, 1935). All tissues were embedded immediately in OCT compound (Miles Inc., Elkhart, IN) and snap-frozen in the mixture of isopentane and solid carbon dioxide as described by Barua et al. (1998a). Cryostat sections of $15 \mu \mathrm{m}$ thickness were air dried on slides treated with 3-aminopropyl-triethoxysilane (Nacalai Tesque, Kyoto) as described by Van Prooijen-Knegt et al. (1982). The sections were then fixed with cold acetone and methanol for $10 \mathrm{~min}$ each.

\section{Antibodies}

Mouse monoclonal anti-chicken MHC class II antibody (Veromaa et al., 1988) was used as the primary antibody. Immunodetection kit S-HRP (Seikagaku Kogyo Co., Tokyo) was used for the detection of immunoprecipitates of primary antibody.

\section{Immunostaining}

Sections were washed with PBS for $15 \mathrm{~min}(3 \times 5 \mathrm{~min})$ and incubated with $1 \%(\mathrm{v} / \mathrm{v})$ normal goat serum for $15 \mathrm{~min}$ to block the non-specific bindings of antibodies. Sections were then incubated overnight with mouse anti-chicken MHC class II antibody diluted with PBS containing $0.5 \%(\mathrm{w} / \mathrm{v}) \mathrm{BSA}$ at a concentration of 1:100, followed by washing with PBS for $15 \mathrm{~min}(3 \times 5 \mathrm{~min})$. Immunoreactions of the first antibody on the sections were detected by S-HRP immunostaining kit according to the manufacturer's instruction. Briefly, the sections were incubated with the biotinylated secondary antibody and with avidin-biotin-peroxidase complex for $1 \mathrm{~h}$ each. Finally, immunoprecipitates were visualized by incubating with a mixture of $0.02 \%(\mathrm{w} / \mathrm{v}) 3^{\prime}, 3^{\prime}$ diaminobenzidine-tetrahydrochloride (Sigma, St. Louis, $\mathrm{MO}$ ) and $0.001 \%(\mathrm{w} / \mathrm{v}) \mathrm{H}_{2} \mathrm{O}_{2}$ in $0.05 \mathrm{~mol}$ Tris- $\mathrm{HCl}^{-1}(\mathrm{pH} 7.6)$. After immunostaining, the sections were counterstained with haematoxylin, dehydrated and covered. Control staining, in which the first antibody was replaced with normal mouse IgG, was carried out simultaneously. No positive staining was found in the control slides.

\section{Counting of $\mathrm{MHC}-\mathrm{II}^{+}$cells}

The MHC-II ${ }^{+}$cells were counted as described by Barua et al. (1998a). Briefly, the sections were examined under a light microscope with software for image analysis (Mac Aspect, Mitani Co., Fukui, Japan). The observations for $\mathrm{MHC}^{-\mathrm{II}^{+}}$cells were made in the ovarian stroma and the theca of primary follicles (approximately $400-600 \mu \mathrm{m}$ in diameter). The numbers of positive cells were obtained by observing three different regions in each theca (approximately $0.5-1.0 \times 10^{4}$ $\mu \mathrm{m}^{2}$ ) and stroma (approximately $3-6 \times 10^{4} \mu \mathrm{m}^{2}$ ). The number of cells in a $1 \times 10^{4} \mu \mathrm{m}^{2}$ area was calculated, and the average of the three counts was expressed as the number of cells in $1 \times 10^{4} \mu \mathrm{m}^{2}$ in one tissue of a bird.

\section{Statistical analysis}

The significance of differences in the positive cell number was determined by one-way ANOVA followed by Duncan's multiple range test.

\section{Results}

The ovarian stroma consisted of the loose connective tissue in which primary follicles were embedded. The primary follicles were composed of the granulosa layer and theca, which contained spindle-shaped fibroblast-like cells. Cells positive for MHC class II immunoreactions were localized in the ovarian stroma and theca layer of primary follicles in all birds examined (Fig. 1). Some of the fibroblast-like cells in the theca layer of primary follicles were positive for $\mathrm{MHC}$ class II immunoreaction. The shape and arrangement of these cells resembled other fibroblast-like cells. In the stroma, the $\mathrm{MHC}-\mathrm{II}^{+}$cells had an oval or irregular appearance. The 

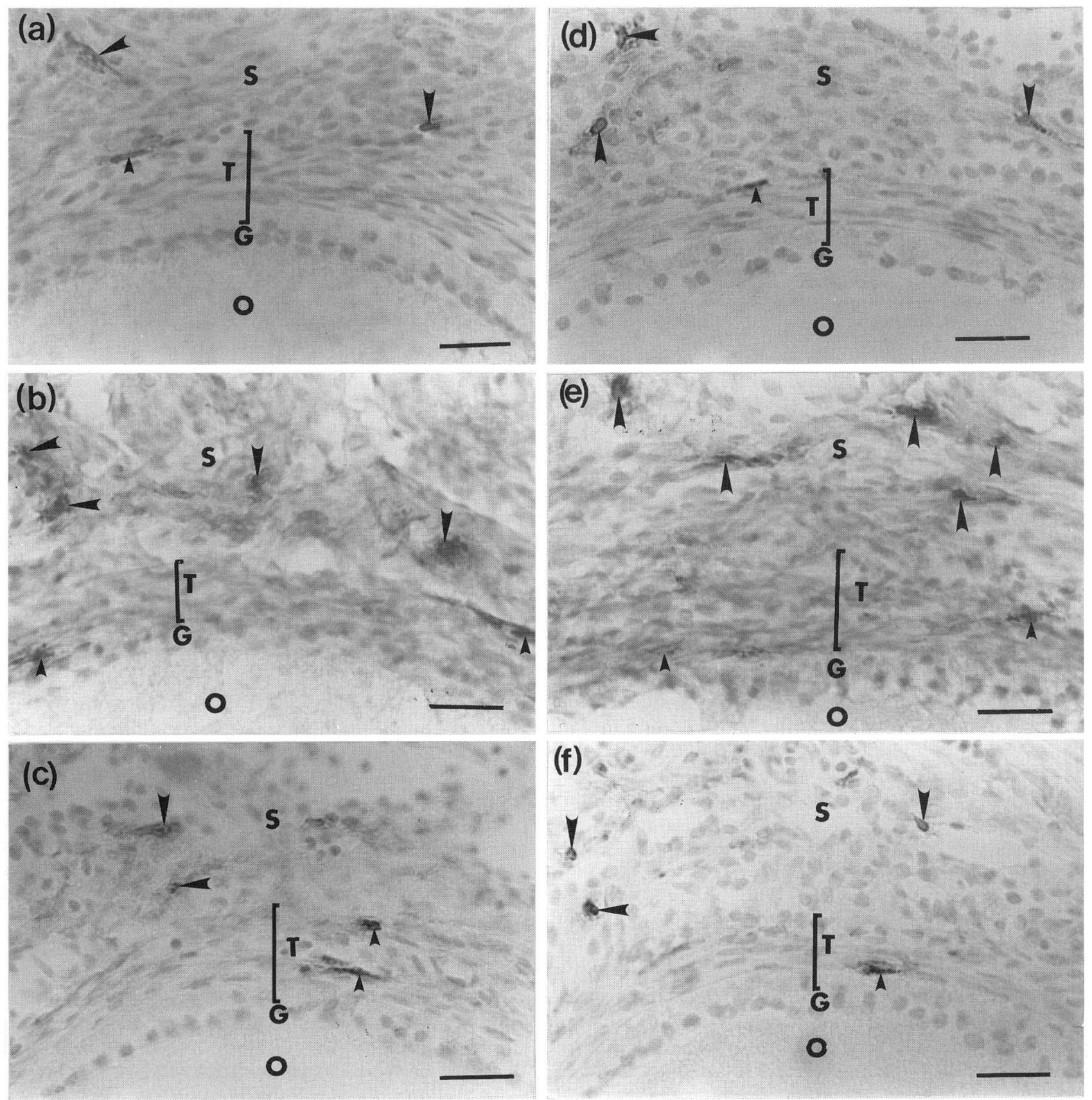

Fig. 1. Chicken ovarian sections immunostained for major histocompatibility complex class II. Small and large arrowheads indicate examples of major histocompatibility complex class II positive (MHC-II ${ }^{+}$) cells in the theca of the primary follicle and in the stroma, respectively. G: Granulosa layer; O: oocyte; T: theca layer; S: stroma. (a) Ovarian stroma of an untreated immature hen. A few MHC-II' cells are observed in the stroma and theca of primary follicle. (b) Ovarian stroma of a young laying hen. The number of MHC-II cells is greater than in an immature non-treated hen. (c) Ovarian stroma of an old laying hen. The number of $\mathrm{MHC}^{-\mathrm{II}^{+}}$cells is lower than in a young laying hen. (d) Ovarian stroma of an immature hen treated with oil. Few MHC-II cells are observed in the ovarian stroma and theca of the primary follicle. (e) Ovarian stroma of a diethylstilboestrol (DES)-treated immature hen. In comparison with oil-treated immature hens, many MHC-II ${ }^{+}$cells are observed in the stroma and theca of the primary follicle. (f) Ovarian stroma of a progesterone-treated

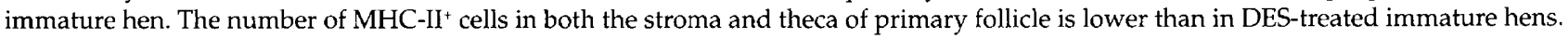
Scale bars represent $20 \mu \mathrm{m}$.

frequency of $\mathrm{MHC}-\mathrm{II}^{+}$cells in the stroma and theca of primary follicles of immature birds was approximately five

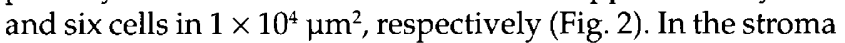
and theca of primary follicles of young laying hens, the frequency of $\mathrm{MHC}-\mathrm{II}^{+}$cells was significantly greater compared with the number in the stroma and theca of primary follicles of immature and old laying hens $(P<0.01)$.

Significant histological differences were not observed in 


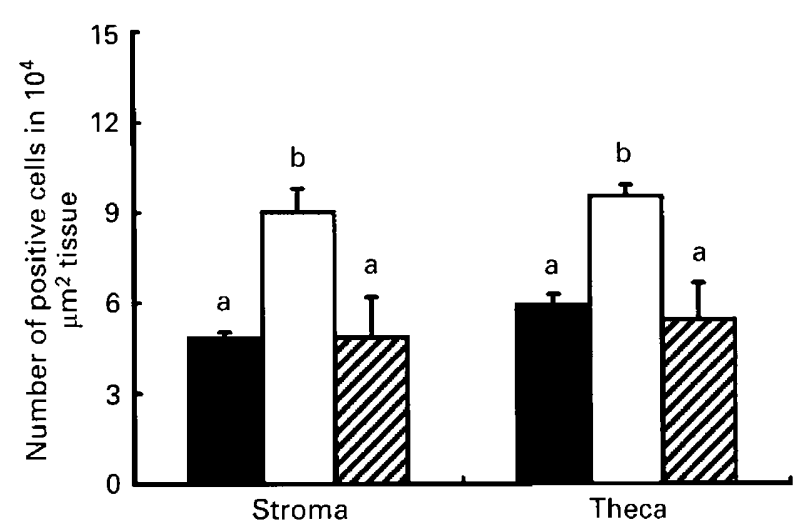

Fig. 2. Frequency of major histocompatibility complex class II positive $\left(\mathrm{MHC}-\mathrm{II}^{+}\right)$cells in the ovarian stroma and theca layer of primary follicles of non-treated immature $(\square)$, young laying $(\square)$ and old laying $(\boldsymbol{Z})$ hens. Each value shows mean \pm SEM of the number of MHC-II ${ }^{+}$cells in $1 \times 10^{4} \mu \mathrm{m}^{2}$ ( $n=5$ birds in each group). Bars with different letters are significantly different $(P<0.01)$.

the ovarian structures among DES-, progesterone- and oiltreated (control) birds (Fig. 1). However, the mass of the oviduct was significantly greater in DES-treated birds $(9.79 \pm$ $0.11 \mathrm{~g} \mathrm{~kg}^{-1}$ body weight) than it was in progesterone-treated $\left(0.42 \pm 0.05 \mathrm{~g} \mathrm{~kg}^{-1}\right.$ body weight) and control birds $(0.35 \pm$ $0.04 \mathrm{~g} \mathrm{~kg}^{-1}$ body weight). The frequencies of $\mathrm{MHC}-\mathrm{II}^{+}$cells in the stroma and theca of primary follicles of immature control birds were approximately 4.5 cells and 4.0 cells in $1 \times$ $10^{4} \mu^{2}$, respectively (Fig. 3). The frequency of $\mathrm{MHC}-\mathrm{II}^{+}$cells was approximately threefold greater in the stroma and theca of primary follicles of DES-treated birds $(P<0.01)$ than in control birds. Progesterone showed no significant effect on the frequency of MHC- $\mathrm{II}^{+}$cells in the ovarian stroma and theca of primary follicles.

\section{Discussion}

This is the first report localizing MHC-II cells in the chicken ovary. ${\mathrm{MHC}-\mathrm{II}^{+}}^{+}$cells play an essential role in disease resistance and may also play a role in ovarian remodelling in mammals. The major findings of the present study are that: (1) MHC-II cells were located in the ovarian stroma and the follicular theca; (2) their frequency was significantly increased as the birds sexually matured and decreased during ageing; and (3) their frequency was significantly increased by DES treatment.

MHC-II ${ }^{+}$cells were observed in the ovarian stroma and theca of primary follicles. In the ovarian stroma many of them were oval or irregular in shape. We assume that some of these cells might be macrophages which were localized in the ovarian stroma of hens (Barua et al., 1998b). In the theca layer of primary follicles, most $\mathrm{MHC}-\mathrm{II}^{+}$cells were the thecal fibroblast-like cells which were spindle-shaped. This result indicates that the thecal fibroblast-like cells are antigen presenting cells.

The population of $\mathrm{MHC}-\mathrm{II}^{+}$cells significantly increased in the ovary of young laying hens as compared with immature

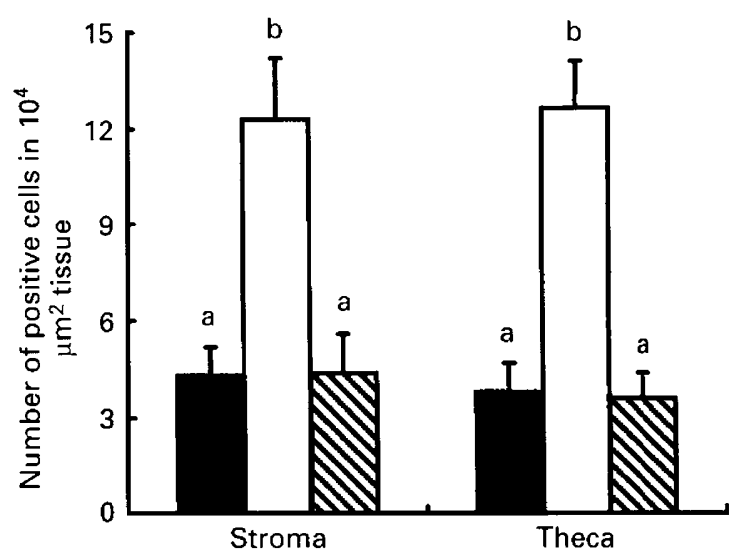

Fig. 3. Frequency of major histocompatibility complex class II positive $\left(\mathrm{MHC}^{\left.-\mathrm{II}^{+}\right)}\right.$cells in the ovarian stroma and theca layer of primary follicles of immature hens treated with or without sex steroids (hens treated with: $\mathbf{\square}$, sesame oil; $\square$, diethylstilboestrol; or $\mathbf{N}$, progesterone). Each value shows mean \pm SEM of the number of MHC-II ${ }^{+}$cells in $1 \times 10^{4} \mu \mathrm{m}^{2}$ ( $n=5$ birds in each group). Bars with different letters are significantly different $(P<0.01)$.

hens and decreased significantly in old laying hens, indicating that the frequency of $\mathrm{MHC}^{-\mathrm{II}^{+}}$cells increases when a bird sexually matures and decreases during ageing. Administration of DES to immature hens increased the frequency of $\mathrm{MHC}-\mathrm{II}^{+}$cells in the ovarian stroma and the theca of primary follicles, whereas progesterone had no effect. Although the effectiveness of progesterone on ovarian tissues could not be confirmed, it has been reported that the treatment of immature birds with the dose of progesterone used in the present study increased the population of $\mathrm{T}$ and $\mathrm{B}$ cells, but not MHC-II+ cells, in the oviduct of immature hens (Zheng et al., 1998). Thus, progesterone may have less effect on the induction of MHC-II ${ }^{+}$cells in both the ovary and oviduct. It remains unknown whether the failure of progesterone to induce MHC- $\mathrm{II}^{+}$cells in the ovary is related to lower progesterone receptor concentrations. Immunoreactive progesterone receptors were increased markedly in the ovary of immature hens by oestrogen treatment (Isola et al., 1987). However, oestrogen may stimulate the induction of MHC class II molecules in hen ovarian cells or the influx of MHC$\mathrm{II}^{+}$cells in the ovary. It is assumed that $\mathrm{MHC}-\mathrm{II}^{+}$cells increase in association with ovarian functions such as steroidogenesis and oogenesis during sexual maturation, and oestrogen may be one of the factors involved in this process. The decrease in MHC-II ${ }^{+}$cell frequency in the ovaries of old laying hens may be related to the decrease in ovarian functions. Decreases in folliculogenesis and steroidogenesis during ageing have been suggested by Bahr and Palmer (1989).

Earlier studies localized macrophages (Barua et al., 1998b), $\mathrm{CD}^{+} \mathrm{T}$ cells (Barua and Yoshimura, 1999) and immunoglobulin-containing cells (Barua et al., 1998a) in the hen ovary. The frequencies of these cells were higher in young laying hens than in immature and old laying hens, and were also increased by oestrogen. Therefore, it is likely that the changes in the frequency of $\mathrm{MHC}^{-\mathrm{II}^{+}}$cells in the ovary resemble those of other immunocompetent cells, including $\mathrm{CD}^{+} \mathrm{T}$ cells, immunoglobulin-containing cells 
and macrophages. An immune response requires a series of cellular interactions, namely, antigen presentation by MHC$\mathrm{II}^{+}$cells, such as macrophages and other antigen-presenting cells, stimulates $\mathrm{CD}^{+} \mathrm{T}$ cells, and activated $\mathrm{CD}^{+} \mathrm{T}$ cells stimulate B cells to produce immunoglobulins. Therefore, since the population of major immunocompetent cells, including $\mathrm{MHC}-\mathrm{II}^{+}$cells and immunoglobulin-containing cells, were affected by these factors, the immune response function in the ovary may be affected by age and oestrogen.

In conclusion, it is suggested that $\mathrm{MHC}-\mathrm{II}^{+}$cells were located in both the ovarian stroma and theca of follicles. Changes in their frequency may be associated with sexual maturation and ageing of birds. Oestrogen may have a role in enhancing the induction of $\mathrm{MHC}-\mathrm{II}^{+}$cells in the ovary.

The authors wish to thank O. Vainio, Department of Medical Microbiology, University of Turku, Finland, for his kind donation of antibody to chicken MHC class II. This work was supported by Grants-in-Aid for Scientific research from the Ministry of Education, Science, Sports and Culture, Japan (No. 10660272), to Y. Yoshimura.

\section{References}

Bahr JM and Palmer SS (1989) The influence of ageing on ovarian function Critical Reviews in Poultry Biology 2 103-110

Barua A and Yoshimura Y (1999) Effects of ageing and sex steroids on the localization of T-cell subsets in the ovary of chicken, Gallus domesticus. General and Comparative Endocrinology 114 28-35

Barua A, Yoshimura Y and Tamura T (1998a) Effects of ageing and oestrogen on the localization of immunoglobulin-containing cells in the chicken ovary Journal of Reproduction and Fertility 114 11-16

Barua A, Yoshimura X and Tamura T (1998b) The effects of age and sex steroids on the macrophage population in the ovary of chicken, Gallus domesticus. Journal of Reproduction and Fertility 114 253-258

Benacerraf B (1981) Role of MHC gene products immune regulation Science $2121129-1138$

Benyo DF, Haibel GF, Laufman HB and Pate JL (1991) Expression of major histocompatibility complex antigens on the bovine corpus luteum during the estrous cycle, luteolysis and early pregnancy Biology of Reproduction 45 229-234

Bland P (1988) Major histocompatibility class II expression by the gut epithelium Immunology Today 9 174-178

Blaxland JD, Cullen GA, Gordon RF and Jordon FTW (1982) Diseases caused by bacteria, mycoplasmas and chlamydia. In Poultry Diseases 2nd Edn pp 9-75 Eds RF Gordon and FTW Jordon. Bailliere Tindall, London

Bottazzo Gf, Pujol-Borrel R, Hanafusa T and Fieldman R (1983) Role of aberrant HLA-DR expression and antigen presentation in the induction of endocrine autoimmunity Lancet ii 1115-1118

Bourlet Y, Behar G, Guillemot F, Frechin N, Billault A, Chausse A (1988)
Isolation of chicken major histocompatibility complex class II (B-L) chain sequences: comparison with mammalian $B$ chains and expression in lymphoid organs European Molecular Biology Journal 7 1031-1039

Fujiwara H, Ueda M, Imai K, Fukuoka M, Yasuda K, Takakura K, Suginami H, Kanzaki H, Inoko H, Mori T and Maeda M (1993) Human leukocyte antigen-DR is a differentiation antigen for human granulosa cells Biology of Reproduction 49 705-715

Head JR and Gaede SD (1986) Ia antigen expression in the rat uterus Journal of Reproductive Immunology 9 137-153

Hill JA and Anderson DJ (1990) Evidence for the existence and significance of immune cells in male and female reproductive tissues Immunology and Allergy Clinics of North America 10 1-12

Hirokawa K (1992) Understanding the mechanism of the age-related decline in immune function Nutrition Reviews 50 361-366

Isola J, Korte J-M and Tuohimaa P (1987) Immunocytochemical localization of progesterone receptor in the chick ovary Endocrinology 121 1030-1040

Keller LH, Benson CE, Krotec K and Eckrode RJ (1995) Salmonella enteritidis colonization of the reproductive tract and forming and freshly laid eggs of chickens Infection and Immunity 63 2443-2449

MacCubbin DL and Schierman LW (1986) MHC-restricted cytotoxic response of chicken T cells: expression, augmentation and clonal characteristics Journal of Immunology 136 12-16

Pate JL (1995) Involvement of immune cells in regulation of ovarian functions Journal of Reproduction and Fertility Suppiement 49 365-377

Petrovska M, Dimitrov DG and Michael SD (1996) Quantitative changes in macrophage distribution in normal mouse ovary over the course of oestrous cycle examined with an image analysis system American Journal of Reproductive Immunology 36 175-183

Prabhala RH and Wira CR (1995) Sex hormone and IL-6 regulation of antigen presentation in the female reproductive tract mucosal tissues fournal of Immunology 155 5566-5573

Tada T (1992) Nutrition and the immune system: an overview Nutrition Revierus $\mathbf{5 0} 360$

Van Prooijen-Knegt AC, Raaf AK, Van Der Berg MJM, Vrolijk J and Van Der Ploeg (1982) Spreading and staining of human metaphase chromosomes on aminoalkyl-silane-treated glass slides Histochemical Journal 14 333-344

Vainio O, Toivanen P and Toivanen A (1987) Major histocompatibility complex and cell cooperation Poultry Science 66 795 -801

Veromaa T, Vainio $O$, Jalkanen S, Eerrola $E$, Cranfors $K$ and Toivanen $P$ (1988) Expression of B-L and Bu-1 antigens in chickens bursectomized $60 \mathrm{~h}$ of incubation European Journal of Immunology 18 225-230

Warren DC and Scott HM (1935) Time factor in poultry production Poultry Science 14 195-207

Yoshimura X and Bahr JM (1991) Localization of progesterone receptors in pre- and postovulatory follicles of domestic hen Endocrinology 128 323-330

Yoshimura Y, Chang C, Okamoto T and Tamura T (1993) Immunolocalization of androgen receptor in the small, preovulatory and postovulatory follicles of laying hens General and Comparative Endocrinology 91 81-89

Yoshimura Y, Okamoto T and Tamura T (1995) Changes in localization of ovarian immunoreactive oestrogen receptor during follicular development in hens General and Comparative Endocrinology 100 1-7

Zheng WM, Yoshimura Y and Tamura T (1998) Effects of age and gonadal steroids on the localization of antigen-presenting cells in the chicken oviduct Journal of Reproduction and Fertility 114 45-54 